\title{
Musculoskeletal Disorders' Classification Proposal for Application in Occupational Medicine
}

\author{
Pablo Monteiro Pereira ${ }^{1} \oplus$, João Amaro ${ }^{2}$, Bruno Tillmann Ribeiro ${ }^{3}$, Ana Gomes ${ }^{4}$, Paulo De Oliveira ${ }^{2}$, \\ Joana Duarte ${ }^{5}\left(\mathbb{D}\right.$, João Ferraz ${ }^{5}$, João Santos Baptista ${ }^{5, * \mathbb{D}}$ and José Torres Costa ${ }^{1}$ \\ 1 Associated Laboratory for Energy, Transports and Aeronautics, (LAETA/ROA), Faculty of Medicine, \\ University of Porto, 4200-319 Porto, Portugal; prof.monpe@outlook.com (P.M.P.); zecatoco@sapo.pt (J.T.C.) \\ 2 Institute of Public Health, University of Porto, 4200-319 Porto, Portugal; amaro.jpc@gmail.com (J.A.); \\ paulo.oliveira.ortopedia@gmail.com (P.D.O.) \\ 3 Occupational Safe and Health Department, IMTEP/PETROBRAS, Macaé 27913-350, Brazil; \\ brunotillmann@gmail.com \\ 4 Occupational Safe and Health Department, Ria Blades/Siemens Gamesa, 3840-346 Vagos, Portugal; \\ hannalleh@gmail.com \\ 5 Associated Laboratory for Energy, Transports and Aeronautics, (LAETA/PROA), Faculty of Engineering, \\ University of Porto, 4200-465 Porto, Portugal; jasduarte@fe.up.pt (J.D.); ferraz.jhm@gmail.com (J.F.) \\ * Correspondence: jsbap@fe.up.pt
}

check for updates

Citation: Pereira, P.M.; Amaro, J.; Ribeiro, B.T.; Gomes, A.; De Oliveira, P.; Duarte, J.; Ferraz, J.; Baptista, J.S.; Costa, J.T. Musculoskeletal Disorders Classification Proposal for Application in Occupational Medicine. Int. J. Environ. Res. Public Health 2021, 18, 8223. https:// doi.org/10.3390/ijerph18158223

Academic Editor: Jin-Hwa Jung

Received: 5 June 2021

Accepted: 29 July 2021

Published: 3 August 2021

Publisher's Note: MDPI stays neutral with regard to jurisdictional claims in published maps and institutional affiliations.

Copyright: (c) 2021 by the authors. Licensee MDPI, Basel, Switzerland. This article is an open access article distributed under the terms and conditions of the Creative Commons Attribution (CC BY) license (https:/ / creativecommons.org/licenses/by/ $4.0 /)$.

\begin{abstract}
Occupational-specific classifications of musculoskeletal disorders (MSD) are scarce and do not answer specific clinical questions. Thus, a specific classification was developed and proposed, covering criteria applicable to daily clinical activity. It was considered that the disorder development process is the same across all work-related MSDs (WRMSDs). Concepts of clinical pathology were applied to the characteristics of WRMSDs pathophysiology, cellular and tissue alterations. Then, the correlation of the inflammatory mechanisms with the injury onset mode was graded into four levels (MSDs 0-3). Criteria of legal, occupational and internal medicine, semiology, physiology and orthopaedics, image medicine and diagnostics were applied. Next, the classification was analysed by experts, two occupational physicians, two physiatrists and occupational physicians and one orthopaedist. This approach will allow WRMSD prevention and improve therapeutic management, preventing injuries from becoming chronic and facilitating communication between occupational health physicians and the other specialities. The four levels tool relate aetiopathogenic, clinical, occupational and radiological concepts into a single classification. This allows for improving the ability to determine a WRMSD and understanding what preventive and therapeutic measures should be taken, avoiding chronicity. The developed tool is straightforward, easy to understand and suitable for WRMSDs, facilitating communication between occupational physicians and physicians from other specialities.
\end{abstract}

Keywords: classification; WRMSD; MSD; occupational diseases; musculoskeletal disorders; occupational health

\section{Introduction}

The classification of musculoskeletal disorders (MSDs), recognised as disorders of tendinous, muscular and articular origin [1], has always been important in the medical field, having been studied for over 100 years [2]. The classification of MSDs embraces a wide variety of disorders, including tendonitis, tendinosis, degenerative joint lesions, arthrosis, and neural involvement by tendon compression. Between 1986 and 2020 alone, and to better understand and more effectively classify MSDs, 74 independent classifications were created in sports. From those 74 classifications, 72 are presented in a systematic review by Hamilton et al. (2015) [2], and two other were published between 2017 and 2020 [3,4].

According to Bahr et al. (2020) [3], the most widely used clinical classification is based on the "onset" of the injury's occurrence, whether sudden or repetitive. However, its 
practical application in identifying some injuries is simplistic and leads to confusion [3], particularly concerning traumatic injuries on injured tissues or gradual injuries. In the last decade, five muscle injury classifications have been updated in sports to improve the MSD classification [4-8].

However, even when updated, MSD classifications in sports cannot be adequately applied in other situations, such as MSDs with an occupational source (work-related musculoskeletal disorders-WRMSDs [9]). This problem occurs in the clinical context when non-acute MSDs are observed, given that most sport classifications are linked to acute or traumatic injuries [10].

According to the pathophysiological context, all MSDs develop from two types of inflammatory mechanisms: acute and chronic. In Table 1, its description, clinical and biochemical findings, and results of the inflammatory process in cell/tissue damage are demonstrated, according to these two inflammatory mechanisms [11-13].

Table 1. Adapted classification criteria based on injury pathophysiology and tissue changes [11-13].

\begin{tabular}{|c|c|c|c|c|c|c|}
\hline Classification & & Description & Clinical Signs & Cytokine & $\begin{array}{l}\text { Duration } \\
\text { Time }\end{array}$ & $\begin{array}{c}\text { Outcomes } \\
\text { Cellular/Tissue }\end{array}$ \\
\hline $\begin{array}{l}\text { Acute } \\
\text { Inflammation }\end{array}$ & $\begin{array}{l}- \\
- \\
-\end{array}$ & $\begin{array}{l}\text { Small vessels dilation. } \\
\text { Increased microvascular } \\
\text { permeability. } \\
\text { Leukocytes migration: the } \\
\text { neutrophils that predominate } \\
\text { in the first } 6 \text { to } 24 \mathrm{~h} \text { are } \\
\text { gradually replaced by } \\
\text { macrophages from } 24 \text { to } 48 \mathrm{~h} \\
\text { after injury. }\end{array}$ & $\begin{array}{ll}- & \text { Pain } \\
- & \text { Fever } \\
- & \text { Edema } \\
- & \text { Blush }\end{array}$ & $\begin{array}{l}\text { TNF } \\
\text { IL-1 } \\
\text { IL-6 } \\
\text { IL-17 } \\
\text { Prostaglandins } \\
\text { Bradykinin } \\
\text { Reactive oxygen } \\
\text { species (ROS) }\end{array}$ & $24-48 \mathrm{~h}$ & $\begin{array}{l}\text { Complete recovery } \\
\text { Reversible cell function } \\
\text { Death cell } \\
\text { Progressive chronic } \\
\text { inflammation }\end{array}$ \\
\hline Transition Period & \multicolumn{6}{|c|}{$\begin{array}{l}\text { Between } 48 \mathrm{~h} \text { and } 7 \text { days, features of acute and chronic inflammation can be found. This period can be called the transition period, in } \\
\text { which the diagnosis of the injury as acute or chronic is not clear. }\end{array}$} \\
\hline $\begin{array}{l}\text { Chronic } \\
\text { Inflammation }\end{array}$ & - & $\begin{array}{l}\text { Long-lasting response starting } \\
48 \mathrm{~h} \text { after injury and lasting for } \\
\text { weeks or months. In this phase, } \\
\text { inflammation, tissue damage, } \\
\text { and recovery attempts coexist } \\
\text { in different combinations. } \\
\text { In most chronic inflammatory } \\
\text { reactions, the dominant cells } \\
\text { are macrophages and T } \\
\text { lymphocytes. }\end{array}$ & $\begin{array}{l}\text { Pain } \\
\text { Atrophy }\end{array}$ & $\begin{array}{l}\text { IL-12 } \\
\text { INF- } \\
\text { IL-17 }\end{array}$ & $\geq 7$ days & $\begin{array}{ll}- & \text { Fibrosis } \\
- & \text { Loss of function } \\
- & \text { Perhaps even tissue } \\
& \text { breakdown may occur. } \\
- & \text { Granulation tissue } \\
- & \text { Neuropathic pain } \\
- & \text { Neural fibrosis } \\
- & \text { Anxiety } \\
- & \text { Depression }\end{array}$ \\
\hline
\end{tabular}

During the MSD pathophysiological analysis in professional environments, it is observed that injuries mainly result from excessive loads or repetitive tasks, with characteristics of over-stretching, compression, friction, ischemia and overexertion [12].

According to Kumar et al. [11], the continual execution of physical activities while the tissue is still inflamed hinders the interruption of the inflammatory cycle. This overload will promote inflammatory progression, leading the inflammation to a state of chronicity caused by structural and morphological changes (Figure 1), making cell damage irreversible.

Thus, considering the pathophysiological concept as a reference, it is possible to verify that the existing classifications within the scope of occupational medicine are limited [14]. Consequently, they can promote an incomplete assessment of the injury, compromising its proper prevention and treatment.

In an occupational medicine context, there are two major classifications for WRMSDs: the classification of the International Labour Organization (ILO) [15] and the type developed by Bernard et al. [16], published by the National Institute for Occupational Safety and Health (NIOSH).

According to ILO, WRMSDs can be classified as occupational diseases, with a codification or as occupational accidents [15]. Any other injury not related to these two categories is considered a work-aggravated disease, according to the International Classification of Diseases (ICD) [17].

According to ICD, 10th edition [17], the classifications referring to MSDs receive a code for classification, which is not applicable for use in a clinical therapeutic context [17]. 


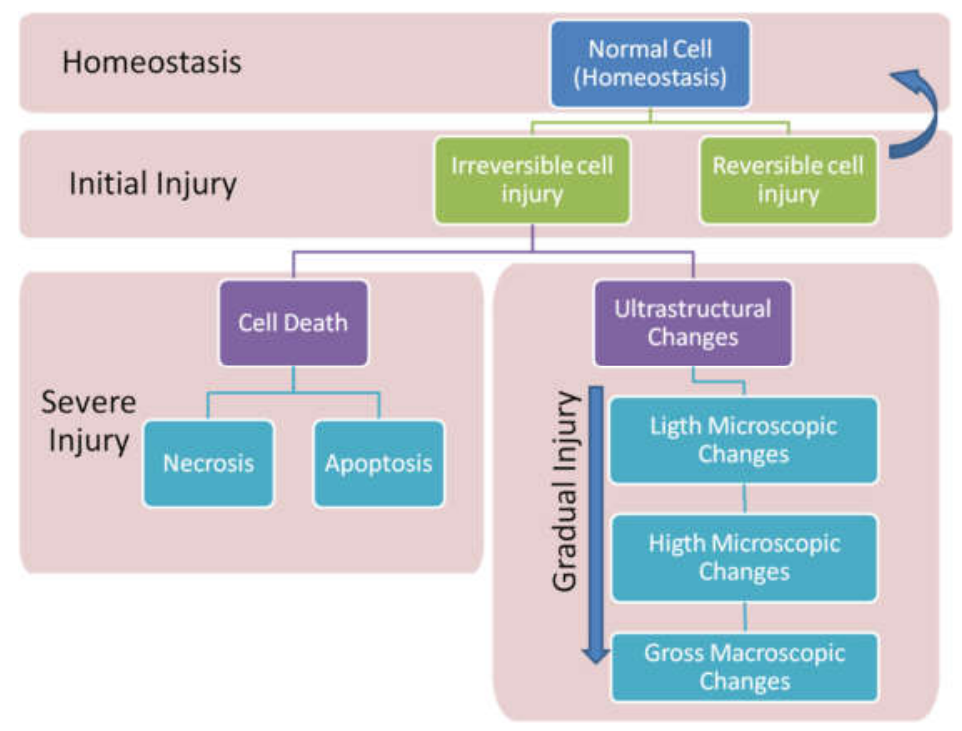

Figure 1. Cellular and tissue regeneration process after injury.

According to NIOSH classification [16], the mechanisms of occurrence of WRMSDs injuries consider the risk factors recognised as occupational. Nevertheless, the significance of Bernard and colleagues' classification [16], in the work context, is restricted to identifying the risk factors that can cause occupational diseases recognised by ILO. However, it does not present information based on injury physiopathology. Despite this lack of information, the use of Bernard's classification was widespread in the occupational health and safety context and the work ergonomics area [18]. Furthermore, it allowed integration of the risk factors. However, its use in occupational medicine is limited because, regardless of the risk factors, workers' health needs to associate a correct diagnosis so that therapy and preventive intervention can be well guided.

The European Agency for Safety and Health at Work (EU-OSHA) defines "WRMSDs when the disorder is caused or aggravated mainly by work and the effects of the immediate environment in which work is performed" [19]. Nevertheless, while this classification is vital in legal matters, it has little applicability in daily practice.

Thus, the significance of existing classifications is recognised. However, it is also concluded that they cannot adequately cover the peculiarities of MSDs in an occupational environment. This limitation makes it challenging to adopt effective therapeutic and preventive measures. In this context, it is necessary to overcome the lack of a specific classification for WMSD that meets occupational medicine's diagnostic and therapeutic needs. So, this work aimed to develop a proposal for the classification of MSDs in the work context, through aetiopathogenic concepts capable of achieving increased practical effectiveness, allowing the prevention of WRMSD to have better therapeutic management and facilitate communication between occupational health physicians and those of other specialities.

\section{General Methodology of Tool Development}

Clinical pathology concepts were applied to the characteristics of MSD pathophysiology and cellular and tissue changes (Table 1). The criteria established for the new classification involved the inflammatory mechanisms and their characterisation. According to the onset, action mechanisms, risk factors involved, clinical signs and symptoms were complementary findings at ultrasound (USG) imaging and magnetic resonance (MR) imaging. Then, the inflammatory mechanisms were correlated with the mode of lesion onset-sudden or gradual and, thus, graded into four classification levels: MSD-0-MSD-3. After defining this grading scale, all other criteria were adapted to the four pre-established levels. Subsequently, legal medicine and occupational medicine criteria were applied to the mechanisms of injury and risk factors. The requirements for the description of signs and symptoms, injury location, time of recovery, and return to activity were evaluated 
using the medical clinic, semiology, physiatry and orthopaedics concepts. Furthermore, the identification of acute and chronic injuries was carried out according to image and diagnostic medicine criteria.

After applying the concepts to all specialities, all tables were reviewed by specialists: two physiatrists and occupational physicians, two occupational physicians and one orthopaedist.

Thus, after addressing each particular aspect, the results were summarised into one table. In total, five partial tables were created. Ultimately, all five tables were, in turn, synthesised into a single classification table.

Finally, the results were tested using those MSDs recognised as occupational by the ILO and compared with the ICD-10 classification.

\section{Tool Development}

It is understood that the processes are continuous, with the possibility of complete or incomplete tissue regeneration without healing (Figure 1). Therefore, the first analysis of the classifications comes from existing concepts and criteria according to clinical pathology (Table 1), distinguishing between acute and chronic inflammatory processes [11-13].

Then, the inflammatory mechanisms defined in Table 1 were correlated with the development of MSD, allowing for the distribution of the classification into four MSD levels (0-3), as shown in Table 2.

Table 2. Criteria according to lesion pathophysiology and onset mode.

\begin{tabular}{ccccc}
\hline \multicolumn{2}{c}{ Classification } & \multicolumn{2}{c}{ Criterion } \\
\hline MSD Type & Onset Mode & Inflammation & Tissue & Tissue Regeneration and Outcome \\
\hline 0 & Late & Acute & Healthy & $\begin{array}{c}\text { Complete tissue regeneration (regeneration } \\
\text { without irreversible cellular changes) }\end{array}$ \\
\hline 1 & Sudden & Acute & Healthy & Complete tissue regeneration without fibrosis \\
\hline 3 & Sudden & Chronic & Healthy or Altered & $\begin{array}{r}\text { Fibrosis/cell death/progressive } \\
\text { chronic inflammation }\end{array}$ \\
\hline & Gradual & Chronic & Altered & $\begin{array}{c}\text { Fibrosis/loss of function/tissue granulation } \\
\text { Neuropathic pain/neural fibrosis }\end{array}$ \\
\hline
\end{tabular}

According to the forensic medicine criteria, Table 3 presents the previously defined scale levels (MSD-0 to MSD-3) relating them to tissue injury mechanisms and the risk factors identified in the workplace. In this assessment, the risk factors were divided into individual (as bone misalignments or muscle imbalances), physical (like vibration or impacts), ergonomic (mainly factors related to the biomechanics of movement) and operational (risks associated with working tasks) $[12,16,18,20]$.

The correlations between MSD scales 0-3 and clinical symptoms, like as pain (visual analogical pain scale [21,22]) and injury zone and treatment (discussed in the internal medicine, orthopaedics, physiatry and medical semiology literature) also used in other international classifications, are shown in Table 4 [3,5,6,8,11,12,23-28].

The relationship between the MSD 0-3 scale and radiological findings is shown in Table 5 . The results are presented descriptively and narratively in this report, supported by previous classifications recognised in the speciality literature $[4-6,8,11,28-30]$. 
Table 3. Classification according to criteria of injury mechanism and risk factors inherent to activities.

\begin{tabular}{|c|c|c|c|c|c|}
\hline \multirow{2}{*}{\multicolumn{2}{|c|}{ Classification }} & \multicolumn{4}{|c|}{ Criterion } \\
\hline & & \multicolumn{4}{|c|}{ Mechanism/Risk Factors } \\
\hline MSD Type & Onset Mode & & Mechanical Action & $\begin{array}{l}\text { Mechanism of Tissue } \\
\text { Injury/Tissue Integrity }\end{array}$ & Risk Factor \\
\hline 0 & Late & - & Tissue trauma due to a tolerable effort & $\begin{array}{l}\text { Alteration of homeostasis with a mild } \\
\text { inflammatory response }\end{array}$ & Absent \\
\hline 1 & Sudden & $\begin{array}{l}- \\
-\end{array}$ & $\begin{array}{l}\text { External direct trauma } \\
\text { Tissue trauma due to excessive effort }\end{array}$ & $\begin{array}{l}\text { Traumatic, generating an episode of } \\
\text { acute inflammation in healthy tissue }\end{array}$ & $\begin{array}{l}\text { Physical } \\
\text { Operational }\end{array}$ \\
\hline 2 & Sudden & $\begin{array}{l}- \\
-\end{array}$ & $\begin{array}{l}\text { External direct trauma } \\
\text { Tissue trauma due to excessive effort }\end{array}$ & $\begin{array}{l}\text { A new episode of acute inflammation } \\
\text { in tissue previously damaged or } \\
\text { inflamed but not fully regenerated. }\end{array}$ & $\begin{array}{l}\text { Individual physical } \\
\text { Ergonomic } \\
\text { Operational }\end{array}$ \\
\hline 3 & Gradual & & $\begin{array}{l}\text { Trauma in the inflamed or fibrous } \\
\text { tissue that may occur with } \\
\text { low-energy effort }\end{array}$ & $\begin{array}{l}\text { Repeated episodes of inflammation } \\
\text { over unregenerated tissue, maintaining } \\
\text { a continuous process of chronic } \\
\text { inflammation. }\end{array}$ & $\begin{array}{l}\text { Individual physical } \\
\text { Ergonomic } \\
\text { Operational }\end{array}$ \\
\hline
\end{tabular}

Table 4. Classification according to criteria for defining signs and symptom regeneration time.

\begin{tabular}{|c|c|c|c|c|c|}
\hline \multirow{2}{*}{\multicolumn{2}{|c|}{ Classification }} & \multicolumn{4}{|c|}{ Criterion } \\
\hline & & \multirow{2}{*}{$\frac{\text { Clinical }}{\text { Signs and Symptoms }}$} & \multirow{2}{*}{$\begin{array}{l}\text { Anatomical } \\
\text { Injury Zone }\end{array}$} & \multicolumn{2}{|c|}{ Treatment } \\
\hline MSD Type & Onset Mode & & & Rest & Rehabilitation \\
\hline 0 & Late & $\begin{array}{l}\text { Mild pain, which worsens with movement, } \\
\text { self-resolving for up to } 48 \mathrm{~h} \text {. }\end{array}$ & $\begin{array}{l}\text { Ligaments/tendons } \\
\text { Muscles }\end{array}$ & No need & No need \\
\hline 1 & Sudden & $\begin{array}{l}\text { Severe pain at the time of injury, progressive, } \\
\text { disabling or not, remaining for days. } \\
\text { Muscular contracture, pain on intense palpation, } \\
\text { sometimes diffuse, local oedema, hyperaemia, } \\
\text { presence of hematoma, pain on movement, } \\
\text { decreased range of motion. }\end{array}$ & $\begin{array}{l}\text { Ligaments/tendons } \\
\text { Joints } \\
\text { Muscles, Bones }\end{array}$ & Need & Need \\
\hline 2 & Sudden & $\begin{array}{l}\text { Acute, constant inflammatory pain worsens with } \\
\text { movement, temporarily incapacitating and may } \\
\text { remain for days to weeks. During palpation or } \\
\text { free movement, moderate to severe pain may or } \\
\text { may not have oedema and haematoma, } \\
\text { decreased range of motion due to fear. }\end{array}$ & $\begin{array}{l}\text { Ligaments/tendons } \\
\text { Joints } \\
\text { Muscles } \\
\text { Bones }\end{array}$ & Need & Need \\
\hline 3 & Gradual & $\begin{array}{l}\text { Chronic inflammatory pain, of moderate to low } \\
\text { intensity, with constant loss of function. Present } \\
\text { during tasks, requiring the use of daily } \\
\text { medication to control pain. It can worsen with } \\
\text { task movement and decrease at rest, often } \\
\text { related to paraesthesia. }\end{array}$ & $\begin{array}{l}\text { Ligaments/tendons } \\
\text { Joints } \\
\text { Muscles } \\
\text { Bones } \\
\text { Nerves }\end{array}$ & Need & Need \\
\hline
\end{tabular}


Table 5. Classification according to Radiological findings criteria (Adapted) $[2,3,5,6]$.

\begin{tabular}{|c|c|c|}
\hline \multicolumn{2}{|c|}{ Classification } & \multirow{2}{*}{$\begin{array}{c}\text { Criterion } \\
\text { Radiology/Complementary Examinations (USG/RM) }\end{array}$} \\
\hline MSD Type & Onset Mode & \\
\hline 0 & Late & Slight exudate oedema. \\
\hline 1 & Sudden ${ }^{b}$ & $\begin{array}{c}\text { "Usually, when necessary, it can be positive for fibre breakage in high-resolution MRI. Intramuscular } \\
\text { haematoma. Oedema (exudate). When partial fibre breakage in high-resolution MRI. Intramuscular } \\
\text { haematoma, fibres, disorganised and thin, surrounded by haematoma and peripheral fluid. When } \\
\text { complete rupture: MRI: Complete discontinuity of muscle fibres, haematoma and retraction of } \\
\text { muscular extremities. USG: Comparable to MRI” [5] }\end{array}$ \\
\hline 2 & Sudden ${ }^{b}$ & $\begin{array}{l}\text { Positive when there is a dislocation or partial or complete rupture of the fibres, probably including } \\
\text { some retraction. It may have oedema and haematoma. Bone remodelling, tendon calcification } \\
\text { processes fibres, disorganised and thin, surrounded by haematoma and peri-fascial fluid.When } \\
\text { complete rupture on MRI: "Complete discontinuity of muscle fibres, haematoma and retraction of } \\
\text { muscular extremities. USG: Comparable to MRI" [5] }\end{array}$ \\
\hline 3 & Gradual & $\begin{array}{l}\text { Positive for the degenerative disorder, often including some ligamentous retraction, atrophy and } \\
\text { dysplasia. One may have oedema and haematoma, bone remodelling, tedious calcification processes. }\end{array}$ \\
\hline
\end{tabular}

\section{Results}

After using the different classification methods and the criteria recognised by different specialities, the tables were combined using the MSD 0-3 scales and all other studied criteria, producing a single classification table representing a summary of the process (Table 6).

Table 6. Classification process summary.

\begin{tabular}{|c|c|c|}
\hline Classification & Description & Keywords \\
\hline MSD 0 & $\begin{array}{l}\text { - Are MSDs related to Late-onset muscle pain, considered the pain and stiffness felt in the } \\
\text { muscles several hours to days after unusual or strenuous exercise? The pain is felt more } \\
\text { intensely } 24 \text { to } 72 \mathrm{~h} \text { after the activity or task. } \\
\text { - } \quad \text { Acute inflammatory process } \\
\text { - } \quad \text { They are self-resolving in } 72 \mathrm{~h} \text {, without the need for further examinations. } \\
\text { - ICD-10: They are considered non-specific myalgia coded as M79.1. } \\
\text { - ILO: They do not have criteria to be considered for occupational diseases. } \\
\text { - } \\
\text { - } \quad \text { USG/MRI: No changes or minor intramuscular oedema } \\
\text { Risk factors: Absent }\end{array}$ & $\begin{array}{c}\text { Late } \\
\text { Acute inflammation } \\
\text { Healthy tissue } \\
\text { Self-resolving }\end{array}$ \\
\hline MSD 1 & $\begin{array}{l}\text { - Traumatic MSD, with injury to the muscle-tendon unit due to excessive force or } \\
\text { SUDDEN extreme stretching, with the possibility of rupture of muscle fibres or tendon. } \\
\text { Local haematoma, severe pain at the time of the injury, progressive, disabling or not, } \\
\text { pain on movement, decreased motion range. } \\
\text { They need therapeutic intervention with ice, NSAID in place, and, in case of rupture, } \\
\text { surgical treatment. } \\
\text { - } \\
\text { - } \\
\text { Necute inflammatory process } \\
\text { rehabilitation in surgical cases and muscle strengthening to return functionality. } \\
\text { - ICD-10: There is a code depending on the injury. } \\
\text { ILO: Work accident } \\
\text { - USG/MRI: Normally, positive findings acute inflammation, Intramuscular haematoma, } \\
\text { surrounded by haematoma. When rupture: Discontinuous muscle fibres (partial or } \\
\text { complete), rupture site is hyper-vascularised and altered in echogenicity, haematoma, } \\
\text { without retraction of muscular extremities. } \\
\text { Risk Factors: physical, operational, individual }\end{array}$ & $\begin{array}{c}\text { Sudden } \\
\text { Acute inflammation } \\
\text { Healthy tissue } \\
\text { Clearance required } \\
\text { Necessary therapy } \\
\text { Rehabilitation only in cases } \\
\text { of disruption }\end{array}$ \\
\hline
\end{tabular}


Table 6. Cont.

\begin{tabular}{|c|c|c|}
\hline Classification & Description & Keywords \\
\hline MSD 2 & $\begin{array}{l}\text { - Traumatic MSD, with injury to the muscle-tendon unit due to excessive force or sudden } \\
\text { extreme stretching, in tissue with scar alteration or an existing inflammatory process. } \\
\text { - They need therapeutic intervention with ice, NSAID in place, and, in case of rupture, } \\
\text { surgical treatment. } \\
\text { - } \\
\text { - } \quad \text { Neceste inflammatory process } \\
\text { rehabilitation in surgical cases and muscle strengthening to return functionality. } \\
\text { - } \text { ICD-10: There is a code depending on the injury. } \\
\text { - ILO: Work accident } \\
\text { - } \\
\text { USG/MRI: Normally, positive findings acute inflammation, Intramuscular haematoma, } \\
\text { surrounded by haematoma. When rupture: Discontinuity of muscle fibres (partial or } \\
\text { complete), haematoma and retraction of muscular extremities. } \\
\text { - Risk factors: physical, operational, ergonomic }\end{array}$ & $\begin{array}{c}\text { Sudden } \\
\text { Acute inflammation } \\
\text { Altered tissue } \\
\text { Clearance required } \\
\text { Pain therapy } \\
\text { Functional rehabilitation }\end{array}$ \\
\hline MSD 3 & $\begin{array}{l}\text { - Gradual progression MSD, with injury to the muscle-tendon unit due to excessive force } \\
\text { or excessive stretching, in tissue with scar alteration or an existing inflammatory process, } \\
\text { chronic, permanent inflammatory process, injury with associated nervous impairment. } \\
-\quad \text { Need therapeutic intervention with ice, NSAIDs, therapies for pain control. } \\
-\quad \text { Chronic inflammatory process. } \\
-\quad \text { Necessary removal from work, change of function, necessary rehabilitation, muscle } \\
\text { strengthening to return strength, return to functional capacity. } \\
\text { - } \text { ICD-10: There is a code depending on the injury. } \\
\text { - ILO: Occupational illness or illness aggravated by work. } \\
-\quad \text { USG/MRI: Positive for degenerative diseases, often including some ligamentous } \\
\text { retraction, atrophy and dysplasia. The patient may have oedema and } \\
\text { haematoma-usually, partial discontinuity of muscle fibres, bone remodelling, tedious } \\
\text { calcification processes. } \\
\text { Risk factors: ergonomic, operational }\end{array}$ & $\begin{array}{c}\text { Gradual } \\
\text { Chronic inflammation } \\
\text { Altered tissue } \\
\text { Clearance needed } \\
\text { Function change } \\
\text { Pain therapy } \\
\text { Functional rehabilitation }\end{array}$ \\
\hline
\end{tabular}

The developed classification was tested for applicability purposes, comparing the classification of MSD 0-3 with occupational musculoskeletal disease codes recognised by ILO and ICD-10 codes (Table 7).

Table 7. Application of different types of classification to MSD recognised by ILO.

\begin{tabular}{|c|c|c|c|c|}
\hline \multirow{3}{*}{ Musculoskeletal Disorders Name } & \multicolumn{4}{|c|}{ Classification } \\
\hline & \multirow{2}{*}{ ILO } & \multirow{2}{*}{ ICD-10 } & \multicolumn{2}{|c|}{ MSD } \\
\hline & & & Sudden & Gradual \\
\hline $\begin{array}{l}\text { Radial styloid tenosynovitis due to repetitive movements, intense efforts and } \\
\text { extreme wrist postures }\end{array}$ & 2.3.1 & M65.4 & 2 & 3 \\
\hline $\begin{array}{l}\text { Chronic tenosynovitis of the hand and wrist due to repetitive movements, } \\
\text { intense efforts and extreme wrist postures }\end{array}$ & 2.3.2 & M65.8 & - & 3 \\
\hline Olecranon bursitis due to prolonged pressure in the elbow region & 2.3 .3 & M70,2 & 2 & - \\
\hline Pre-patellar bursitis due to prolonged kneeling & 2.3 .4 & M70.4 & 2 & - \\
\hline Repetitive and intense work epicondylitis & 2.3 .5 & M77.1 & 2 & 3 \\
\hline Meniscus injuries after long periods of work in a kneeling or crouching position & 2.3 .6 & M23.3 & 2 & 3 \\
\hline $\begin{array}{l}\text { Carpal tunnel syndrome due to long periods of repetitive and intense work, } \\
\text { work that involves vibration, extreme wrist postures or a combination of all three }\end{array}$ & 2.3.7 & G56.0 & - & 3 \\
\hline
\end{tabular}

In order to simplify the clinical application of the scale, a decision flowchart was developed (Figure 2). This flowchart can be an important visual tool for daily clinical use. It can be directly applied as long as there is a perfect understanding of the defined criteria for each classification level. Detailed classification criteria are presented in Table 6. 


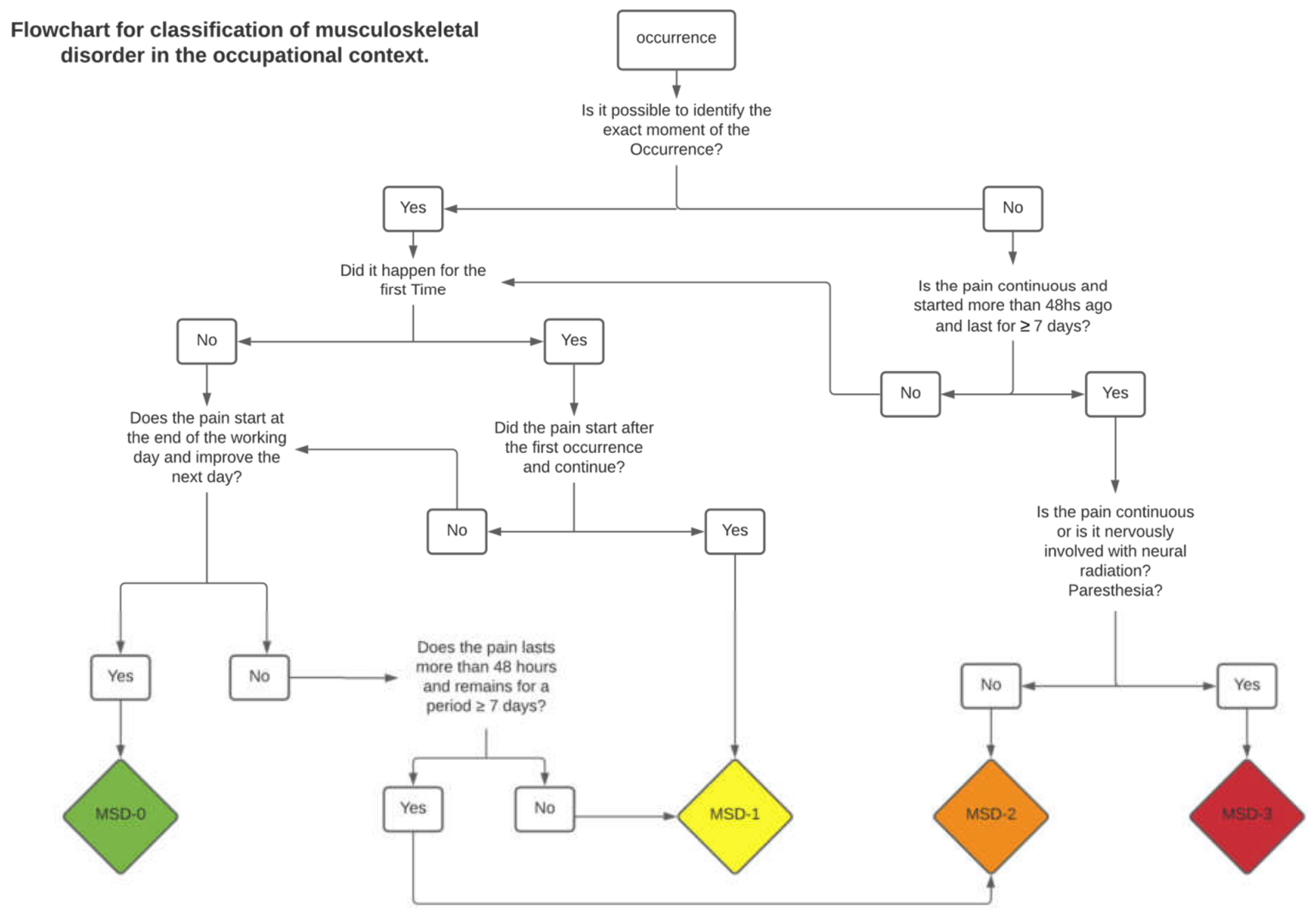

Figure 2. Flowchart for clinical decision in Occupational Context.

\section{Discussion}

Considering WRMSD prevalence in approximately $60 \%$ of all work-related complaints [16], developing a classification for specific application to these diseases is an important issue. This requirement is primarily for clinical practice because it enables appropriate care management for patients and staff, improving well-being at work $[15,18,19,31,32]$.

Considering the classifications of MSDs presented between 1896 and 2020 in the scope of sports, Hamilton et al. (2015) [2] chronologically divided these classifications into (a) "Era Clinic" (1900-1980); (b) "Era of the Image" (1985-2000), and (c) "Modern Era" (from the 2000s). However, despite the vast literature on MSD classifications presented during this period in the scope of sports, they are not fully applicable in the work context $[2-8,33]$.

Therefore, typically in the work context, both ILO and ICD-10 classifications are used. Nevertheless, they are of little relevance in occupational clinical practice and do not provide criteria for better disorder management. Thus, the importance of these classifications is limited to the statistical purposes of data collection because they allow the existence of a single language between countries, as observed in the EU-OSHA annual reports [34].

According to ILO, WRMSDs are recognised as (a) "occupational accident: an unexpected and unplanned occurrence, including acts of violence, arising out of or in connection with work which results in one or more workers incurring a personal injury, disease or death" (Resolution concerning statistics of occupational injuries (resulting from occupational accidents)-1988- ISCO 88, adopted by the 16th International Conference of Labour Statisticians (October 1998)); (b) WRMSD is "[...] any disease contracted as a result of an exposure to risk factors arising from work activity" [15] and "[...] disease contracted as a result of an exposure over a specific period of time to risk factors arising from work activity" [19].

MSDs not present in the ILO's list of occupational diseases [15] are referred to as MSD aggravated by work, that is, resulting from work tasks. However, it is not possible 
to fit them correctly into the work context. They are often considered natural diseases aggravated by work activities that do not describe the MSD occurrence mechanism.

The ILO and ICD-10 classifications do not describe the MSD occurrence mechanism. They also do not state whether the disorder occurred suddenly or gradually, nor do they define whether there is a specific type of therapeutic intervention or whether it is necessary to remove the worker from their work. Thus, these classifications do not allow for the best therapeutic guidance because they do not classify multiple criteria.

The recognition and determination of a work-related disease appear to be of financial interest to states, the employer and the employee who has suffered the injury, and they are also relevant to social security services $[35,36]$. The recognition that a worker's injury or illness is professional can allow the use of this information to adjust activities and change the tasks. However, this recognition also shows that the prevention of MSDs was not enough $[37,38]$ and that there was incorrect management of the initial lesion, allowing its evolution to chronicity.

The most important for occupational medicine is preventing and treating workers' MSD thoroughly $[39,40]$, allowing reversible MSD to be adequately managed, avoiding worsening and chronicity.

Therefore, descriptively divided into four levels (MSD 0-3), the developed tool is easy to understand, enabling the inclusion of any WRMSD, present or not in the ILO list. Thus, it is essential to integrate aetiopathogenic, clinical, occupational and radiological concepts into a single classification, improving the ability to determine WRMSD and understanding what preventive and therapeutic measures should be adopted.

The proposed classification facilitates communication between clinical and occupational physicians. This approach also demonstrates to other professionals in the occupational health and safety area the importance of inflammatory processes being diagnosed and treated early in the disease, preventing its progression to chronicity.

\section{Conclusions}

Reporting to the occupational context, the existing ILO and ICD-10 classifications for MSDs are not particularly useful in health prevention and promotion in the scope of occupational medicine. They are limited to classifying the disease, not predicting any intervention. Thus, its application does not point to intervention paths that may occur when the disorder has already established itself and is irreversible. These classifications are applicable in the context of data collection but are not very functional in medical practices.

Therefore, a classification that includes criteria applicable clinically and allows for better management of the events is essential to prevent a reversible MSD from becoming irreversible.

In the clinical practice of evaluating WRMSD, considering the inflammatory criteria for the proper removal of the employee helps to prevent diseases and to promote health at work. Therefore, such an evaluation has repercussions on workers' health, the company's operating environment and the employee's socioeconomic context. Thus, the return or permanence of a worker in a given occupational task, with an inflammatory process that still exists (active), is a critical measure that must be avoided.

The developed tool can improve WRMSD management, enhance communication between medical professionals of different specialities and increase understanding of the disorder process for other work and professional industrial areas.

Despite being aware that each WRMSD has specificity related to risk factors, the disorder development process remains the same. This is precisely the purpose of the classification presented in this study, which used the previous MSDs concepts and classifications in developing the proposed assessment tool. The usefulness of the developed tool goes beyond classification. It improves understanding of the disorder, identifying the time of the intervention and the need to prevent injuries or their worsening.

Future studies are required to analyse specific WRMSD recovery times, disease prevention, work-task protocols and the hours necessary for job turnover considering the specificities of WRMSDs with work tasks. 
Author Contributions: Conceptualisation, P.M.P., J.T.C.; methodology, P.M.P., J.T.C.; validation, J.A., B.T.R., A.G., P.D.O., J.D., J.F. and J.S.B.; formal analysis, J.A., B.T.R., A.G., P.D.O., J.D., J.F. and J.S.B.; investigation, P.M.P.; resources, P.M.P. and J.S.B.; data curation, P.M.P.; writing-original draft preparation, P.M.P.; writing-review and editing, P.M.P., J.A., B.T.R., A.G., J.T.C., P.D.O., J.D., J.F. and J.S.B.; visualisation, J.A., B.T.R., A.G., J.T.C., P.D.O., J.D., J.F. and J.S.B.; supervision, J.S.B. and J.T.C.; funding acquisition, J.S.B. and J.T.C. All authors have read and agreed to the published version of the manuscript.

Funding: This research was funded by the Doctoral Program in Occupational Safety and Health of the University of Porto, grant number demssojsb541344.

Institutional Review Board Statement: Not applicable.

Informed Consent Statement: Not applicable.

Data Availability Statement: Not applicable.

Acknowledgments: The authors would like to thank all the experts contributing to the presented results with their experience and opinion.

Conflicts of Interest: The authors declare no conflict of interest. The funders had no role in the study's design, collection, analyses, interpretation of data, the writing of the manuscript or the decision to publish the results.

\section{References}

1. Crossley, K.M.; Stefanik, J.J.; Selfe, J.; Collins, N.J.; Davis, I.S.; Powers, C.M.; McConnell, J.; Vicenzino, B.; Bazett-Jones, D.M.; Esculier, J.-F.F.; et al. 2016 Patellofemoral pain consensus statement from the 4th International Patellofemoral Pain Research Retreat, Manchester. Part 1: Terminology, definitions, clinical examination, natural history, patellofemoral osteoarthritis and patient-reported outcome m. Br. J. Sports Med. 2016, 50, 839-843. [CrossRef] [PubMed]

2. Hamilton, B.; Valle, X.; Rodas, G.; Til, L.; Grive, R.P.; Rincon, J.A.G.; Tol, J.L. Classification and grading of muscle injuries: A narrative review. Br. J. Sports Med. 2015, 49, 306. [CrossRef]

3. Bahr, R.; Clarsen, B.; Derman, W.; Dvorak, J.; Emery, C.A.; Finch, C.F.; Hägglund, M.; Junge, A.; Kemp, S.; Khan, K.M.; et al. International Olympic Committee consensus statement: Methods for recording and reporting of epidemiological data on injury and illness in sport 2020 (including STROBE Extension for Sport Injury and Illness Surveillance (STROBE-SIIS)). Br. J. Sports Med. 2020, 54, 372-389. [CrossRef] [PubMed]

4. Valle, X.; Alentorn-Geli, E.; Tol, J.L.; Hamilton, B.; Garrett, W.E.; Pruna, R.; Til, L.; Gutierrez, J.A.; Alomar, X.; Balius, R.; et al. Muscle Injuries in Sports: A New Evidence-Informed and Expert Consensus-Based Classification with Clinical Application. Sports Med. 2017, 47, 1241-1253. [CrossRef] [PubMed]

5. Chan, O.; Del Buono, A.; Best, T.M.; Maffulli, N. Acute muscle strain injuries: A proposed new classification system. Knee Surg. Sports Traumatol. Arthrosc. 2012, 20, 2356-2362. [CrossRef]

6. Mueller-Wohlfahrt, H.W.; Haensel, L.; Mithoefer, K.; Ekstrand, J.; English, B.; McNally, S.; Orchard, J.; Van Dijk, N.; Kerkhoffs, G.M.; Schamasch, P.; et al. Terminology and classification of muscle injuries in sport: The Munich consensus statement. Br. J. Sports Med. 2013, 47, 342-350. [CrossRef]

7. Pollock, N.; James, S.L.J.; Lee, J.C. British athletics muscle injury classification: A new grading system. Br. J. Sports Med. 2014, 48, 1347-1351. [CrossRef]

8. Tscholl, P.; Meynard, T.; Le Thanh, N.; Neroladaki, A. Diagnostics and classification of muscle injuries in sports. Swiss Sports Exerc. Med. 2018, 66, 8-15. [CrossRef]

9. Houvet, P.; Obert, L. Upper limb cumulative trauma disorders for the orthopaedic surgeon. Orthop. Traumatol. Surg. Res. 2013, 99, S104-S114. [CrossRef] [PubMed]

10. Hamilton, B.; Alonso, J.M.; Best, T.M. Time for a paradigm shift in the classification of muscle injuries. J. Sport Health Sci. 2017, 6, 255-261. [CrossRef] [PubMed]

11. Banasik, J.; Copstead-Kirkhorn, L.-E. Study Guide for Pathophysiology, 5th ed.; Saunders: Saint Louis, MO, USA, 2013; ISBN 9780323293181.

12. Barbe, M.F.; Barr, A.E. Inflammation and the pathophysiology of work-related musculoskeletal disorders. Brain Behav. Immun. 2006, 20, 423-429. [CrossRef]

13. Kumar, V.; Abbas, A.K.; Aster, J.C. Robbins Basic Pathology; Elsevier: Amsterdam, The Netherlands, 2018; pp. 775-776. ISBN 9780323353175.

14. Van der Molen, H.F.; Visser, S.; Alfonso, J.H.; Curti, S.; Mattioli, S.; Rempel, D.; Roquelaure, Y.; Kuijer, P.P.F.M.; Tamminga, S.J. Diagnostic criteria for musculoskeletal disorders for use in occupational healthcare or research: A scoping review of consensusand synthesised-based case definitions. BMC Musculoskelet. Disord. 2021, 22, 169. [CrossRef] [PubMed] 
15. International Labour Organization. List of Occupational Diseases (Revised 2010) Identification and Recognition of Occupational Diseases: Criteria for Incorporating Diseases in the ILO List of Occupational Diseases; Occupation; International Labour Organization (ILO): Geneva, Switzerland, 2010; Volume 74, ISBN 9788578110796.

16. Bernard, B.P.; Putz-Anderson, V.; Burt, S.E.; Cole, L.L.; Fairfield-Estill, C.; Fine, L.J.; Grant, K.A.; Gjessing, C.; Jenkins, L.; Hurrell, J.J., Jr.; et al. Musculoskeletal Disorders and Workplace Factors: A Critical Review of Epidemiologic Evidence for WRMDs; Bernard, B.P., Ed.; NIOSH: Cincinnati, OH, USA, 1997.

17. World Health Organization. ICD-10: International Statistical Classificarion of Diseases and Related Health Problems, 2nd ed.; 10th Revision; World Health Organization (WHO): Geneva, Switzerland, 2004; Volume 2, ISBN 9241546530.

18. Leineweber, C.; Marklund, S.; Gustafsson, K.; Helgesson, M. Work environment risk factors for the duration of all cause and diagnose-specific sickness absence among healthcare workers in Sweden: A prospective study. Occup. Environ. Med. 2020, 77, 782-789. [CrossRef]

19. De Kok, J.; Vroonhof, P.; Snijders, J.; Roullis, G.; Clarke, M.; Peereboom, K.; van Dorst, P.; Isusi, I. Work-Related Musculoskeletal Disorders: Prevalence, Costs and Demographics in the EU; EU-OSHA: Luxembourg, 2019; Volume 215.

20. ILO. International Standard Classification of Occupations-(ISCO-88), 1988 ed.; International Labour Organization (ILO): Geneva, Switzerland, 1991; ISBN 9221148327.

21. Gift, A.G. Visual analogue scales: Measurement of subjective phenomena. Nurs. Res. 1989, 38, 286-288. [CrossRef]

22. Ferreira, G.L.; Flynn, M.N. Análise da aplicabilidade de três instrumentos de avaliação de dor em distintas unidades de atendimento: Ambulatório, enfermaria e urgência. Rev. Bras. Reum. 2012, 34, 128-139.

23. Levangie, P.K. Joint structure and function. Arthritis Rheum. 2005, 262-264. [CrossRef]

24. Moore, K.L. Anatomia Orientada para Clínica-Moore, 7a Edição; 7o; Editora Guanabara Koogan Ltda.: Rio de Janeiro, Brazil, 2014; Volume 66, ISBN 9788527725842.

25. Cohen, M. Tratado de Ortopedia; Hardcover; ROCA: São Paulo, Brazil, 2007; ISBN 9788572417006.

26. Jameson, L.; Fauci, A.; Braunwald, E.; Kasper, D.; Hauser, S.L.; Longo, D.; Loscalzo, J. Harrisons Principles of Internal Medicine, 20th ed.; McGraw-Hill Education/Medical: Philadelphia, PA, USA, 2018.

27. Porto, C.C.; Porto, A.L. Semiologia Médica; Porto, A.L., Ed.; Guanabara Koogan: Rio de Janeiro, Brazil, 2019; ISBN 9788527734714.

28. Patel, A.M. LANGE Instant Access Orthopedics and Sports Medicine; LANGE Instant Access; McGraw-Hill Education: New York, NY, USA, 2007; ISBN 9780071594851.

29. Möller, M.; Kälebo, P.; Tidebrant, G.; Movin, T.; Karlsson, J. The ultrasonographic appearance of the ruptured Achilles tendon during healing: A longitudinal evaluation of surgical and nonsurgical treatment, with comparisons to MRI appearance. Knee Surg. Sports Traumatol. Arthrosc. 2002, 10, 49-56. [CrossRef]

30. Takebayashi, S.; Takasawa, H.; Banzai, Y.; Miki, H.; Sasaki, R.; Itoh, Y.; Matsubara, S. Sonographic Findings in Muscle Strain Injury: Clinical and MR Imaging Correlation. J. Ultrasound Med. 1995, 14, 899-905. [CrossRef] [PubMed]

31. Parent-Thirion, A.; Biletta, I.; Cabrita, J.; Vargas Llave, O.; Vermeylen, G.; Wilczyńska, A.; Wilkens, M. Sixth European Working Conditions Survey-Overview Report; (2017 update); Eurofound: Luxembourg, 2017.

32. Akbarzadeh Khorshidi, H.; Hassani-Mahmooei, B.; Haffari, G. An Interpretable Algorithm on Post-injury Health Service Utilization Patterns to Predict Injury Outcomes. J. Occup. Rehabil. 2020, 30, 331-342. [CrossRef]

33. Orchard, J.W.; Meeuwisse, W.; Derman, W.; Hägglund, M.; Soligard, T.; Schwellnus, M.; Bahr, R. Sport Medicine Diagnostic Coding System (SMDCS) and the Orchard Sports Injury and Illness Classification System (OSIICS): Revised 2020 consensus versions. Br. J. Sports Med. 2020, 54, 397-401. [CrossRef]

34. Schneider, E.; Irastorza, X.; Copsey, S. OSH in Figures: Stress at Work—Facts and Figures; Work, European Agency for Safety and Health: Bilbao, Spain, 2010; Volume 179. [CrossRef]

35. Donovan, M.; Khan, A.; Johnston, V. The Contribution of Onsite Physiotherapy to an Integrated Model for Managing Work Injuries: A Follow up Study. J. Occup. Rehabil. 2020, 31, 207-218. [CrossRef]

36. Etuknwa, A.; Daniels, K.; Eib, C. Sustainable Return to Work: A Systematic Review Focusing on Personal and Social Factors. J. Occup. Rehabil. 2019, 29, 679-700. [CrossRef] [PubMed]

37. Abásolo, L.; Carmona, L.; Hernández-García, C.; Lajas, C.; Loza, E.; Blanco, M.; Candelas, G.; Fernández-Gutiérrez, B.; Jover, J.A. Musculoskeletal work disability for clinicians: Time course and effectiveness of a specialized intervention program by diagnosis. Arthritis Rheum. 2007, 57, 335-342. [CrossRef] [PubMed]

38. Hubertsson, J.; Englund, M.; Hallgårde, U.; Lidwall, U.; Löfvendahl, S.; Petersson, I.F. Sick leave patterns in common musculoskeletal disorders-A study of doctor prescribed sick leave. BMC Musculoskelet. Disord. 2014, 15, 176. [CrossRef]

39. Heinemann, A.W.; Feuerstein, M.; Frontera, W.R.; Gard, S.A.; Kaminsky, L.A.; Negrini, S.; Richards, L.G.; Vallée, C. Rehabilitation Is a Global Health Priority. J. Occup. Rehabil. 2020, 30, 153-155. [CrossRef] [PubMed]

40. Steenstra, I.A.; Munhall, C.; Irvin, E.; Oranye, N.; Passmore, S.; Van Eerd, D.; Mahood, Q.; Hogg-Johnson, S. Systematic Review of Prognostic Factors for Return to Work in Workers with Sub Acute and Chronic Low Back Pain. J. Occup. Rehabil. 2017, 27, 369-381. [CrossRef] 